\title{
Effect of alkali doping on CIGS photovoltaic ceramic tiles
}

\author{
D. Fraga $^{*, 1}$, T. Stoyanova Lyubenova ${ }^{1}$, R. Martí ${ }^{1}$, I. Calvet ${ }^{1}$, E. Barrachina ${ }^{1}$ and J.B. \\ $\operatorname{Carda}^{1}$ \\ ${ }^{1}$ Departamento de Química Inorgánica y Orgánica, Universitat Jaume I, Av. de Vicent \\ Sos Baynat s/n, 12071, Castellón (Spain)
}
*Corresponding autor: Tel.: +34964728234; Fax: +34964729016
E-mail adress: fraga@uji.es

\begin{abstract}
This report studies the influence of alkali elements $(\mathrm{Na}, \mathrm{K})$ to morphological, structural and optoelectronic properties of CIGS ceramic tile solar cell. Several ceramic enamels with altered chemical composition in terms of amount of alkali elements have been tested and compared. The influences of alkali type, its quantity and transfer mechanism have been investigated. The solar cell device has been assembled and characterized.

The achieved results indicate that alkali elements ( $\mathrm{Na}$ and $\mathrm{K}$ combination) modified the surface roughness and its diffusion from the enamel toward the absorber affect to the structural and final optoelectronic properties of the device. The alkali doping improve the Ga incorporation in the crystal lattice and an increasing in open circuit voltage (Voc) values, fill factor (FF) and the device efficiency. Optimal alkali quantities have been also determined. The best conversion efficiency is achieved for the cell with $4 \% \mathrm{wt}$ $\mathrm{Na}_{2} \mathrm{O}$ and $3.2 \%$ wt $\mathrm{K}_{2} \mathrm{O}$ (Eff. $=3,5 \%$ ), which presents an improvement of $30 \%$ in
\end{abstract}


efficiency relative to the standard (STD) solar cell sample chosen for comparative purposes.

Keywords: CIGS solar cell; ceramic enamel; sodium; potassium 


\section{Introduction}

Thin film technology have several potential advantages to Si for PV applications, such as better light absorption (10-110 times more efficient), allowing the use of very thin absorbers (ranging from 1.5 to $3 \mu \mathrm{m}$ in contrast to hundred microns for $\mathrm{Si}$ ) and thus less materials use for the fabrication of solar cells (El Chaar, et al. 2011; Park, et al. 2012; Todorov, et al. 2006; Todorov, et al. 2013; Jung, et al. 2010; Contreras, et al. 2006; Reinhard, et al. 2013). They can easily be integrated on several kinds of substrates as soda-lime glass (Zhang, et al. 2014; Furue, et al. 2013; Park, et al. 2011), light weight polymers (Reinhard, et al. 2015; Chirilă, et al. 2011; Caballero, et al. 2011), stainless steel (Pianezzi, et al. 2012; Liang, et al. 2016; Wuerz, et al. 2012) and ceramics (Fraga, et al. 2016; Calvet, et al. 2015; Fraga, et al. 2015; Calvet, et al. 2015). The $\mathrm{Cu}(\mathrm{In}, \mathrm{Ga})(\mathrm{S}, \mathrm{Se}) 2$ chalcopyrites- based (CIGS) thin film technology had been already manufactured and demonstrates higher efficiencies than those achieved by polycrystalline Si (with record values of $22.1 \%$ and $22.3 \%$, respectively) even their lower production costs.

The addition of $\mathrm{Na}$ is an important feature for the CIGS thin film solar cells, since it directly affects to the crystallinity, morphology and opto-electronic properties of the PV device (Salomé, et al. 2015; Theelen and Daume 2016; Rudmann, et al. 2005; Eid, et al. 2015). Potential role of sodium (Na) doping for improvement of device efficiency have been already investigated, but not in details. So far, it have been reported that Na selfdifused from the glass substrate towards the absorber layer and benefits the cell properties. Thus, many authors starts to add it by dropping NaI into the absorber paste before or during CIGS growth or as Na post deposition treatment (PDT) after CIGS growth (He, et al. 2016; Hsu, et al. 2015; Moriwaki, et al. 2015; Wuerz, et al. 2011). Few studies on alkali elements such as potassium $(\mathrm{K})$ have been also reported (Salomé, 
et al. 2015; Reinhard, et al. 2015; Laemmle, et al. 2015). Althought, there are no clear information concerning the alkali effect on the cell proeperties, nighher any quantification of how many is needed to improve the photovotaic device.

Here we are presenting, the influences of alkali elements ( $\mathrm{Na}$ and $\mathrm{K}$ ) on the CIGS solar cell properties. We have also tried to measure the minimum quantity necessary to provide efficiency improvements and to ascertain the doping mechanism comparing with device without any dopants. In this report, we are performing a discussion on PV ceramic tiles with CIGS absorber. Several ceramic supports have been selected for the study based on enamels with varying chemical compositions according the alkali content. The ceramic substrate for CIGS solar cells requires adequate adjustment. Thus, an introduction of extra layer based on enamel is necessary (Fraga, et al. 2015; Fraga, et al. 2016) and also simulates glass surface. The enamel acts as an intermediate barrier between Mo back contact coating and the substrate providing chemical stability simulating glass surface with no porosity. In addition, the enamel also prevents diffusions from the clayey support to the Mo and the absorber CIGS layer and acts as $\mathrm{Na}$ and $\mathrm{K}$ source (Lee, et al. 2015; Becerril-Romero, et al. 2016). The mechanism process and quantification of the alkali dopants have been investigated. The solar cells have been completed and fully characterised with comparison purposes.

\section{Experimental details}

\subsection{Ceramic substrate}

Porcelain stoneware tiles were made by traditional industrial ceramic method of preparation that includes pressing and further sintering of green bodies in a conventional roller kiln (Casasola, et al. 2011). The ceramic bodies were covered by different industrial enamels to protect the surface roughness and to provide $\mathrm{Na}$ and $\mathrm{K}$ 
elements as dopants. Enamels are produced by frits. Frits are prepared from a mixture of raw materials (quartz, feldspar, kaolin, etc) and obtained by fusion and rapid cooling (Nandi, et al. 2015; Siligardi, et al. 2014). The enamels are formed by a vitreous structure $\left(\mathrm{SiO}_{2}, \mathrm{~B}_{2} \mathrm{O}_{3}\right.$ o $\left.\mathrm{P}_{2} \mathrm{O}_{5}\right)$, modifiers network elements ( $\mathrm{Li}, \mathrm{Na}, \mathrm{K}, \mathrm{Ca}, \mathrm{Ba}, \mathrm{Mg}, \mathrm{Pb}$, Sr o $\mathrm{Zn}$ ) and stabilized (mainly $\mathrm{Al}_{2} \mathrm{O}_{3}$ ).

Several samples have been studied in this report. First, standard enamel, referred as STD, was selected for comparison reason. The alkali elements in it composition are fixed as a minimum quantity necessary to prepare enamel with adequate physical and chemical properties. Stand on this, the rest of the samples are composed by different amount of alkalis (Table 1). An increasing in $\mathrm{Na}_{2} \mathrm{O}$ content is proposed for samples $\mathrm{A}$, B, C and D (starting from $1 \%$ for the STD sample to $2 \%$ for A, $2 \%$ for $\mathrm{B}, 4 \%$ for $\mathrm{C}$ and $6.64 \%$ for $\mathrm{D}$ sample). The difference between samples $\mathrm{A}$ and $\mathrm{B}$ are in the $\mathrm{K}_{2} \mathrm{O}$ content (Table 1). The $\mathrm{K}_{2} \mathrm{O}$ is complementary and act as compensating agent to the $\mathrm{Na}_{2} \mathrm{O}$ in the compositions. Thus, various percentages are tested in agreement with the enamel requirements (Table 1). In the literature has been reported that higher contain than $8 \%$ of $\mathrm{Na}_{2} \mathrm{O}$ could provide cracks and pinholes on the enamel surface (Becerril-Romero, et al. 2016), so this amount was selected as maximum alkali $\left(\mathrm{Na}_{2} \mathrm{O}+\mathrm{K}_{2} \mathrm{O}\right)$ content in this work.

It had to me mentioned that a "ceramic tile without enamel" had been prepared for comparative reason to display the role of the vitreous layer. This photovoltaic tile was made identically as the others in this paper, but without enamel, so the Mo back contact coating was directly deposited to the ceramic substrate followed by the absorber layer and the rest of the cell components.

\subsection{CIGS synthesis and deposition}


$\mathrm{CuIn}_{0.7} \mathrm{Ga}_{0.3} \mathrm{Se}_{2}$ solid solution was synthesized using co-precipitation route and further deposited by doctor Blade technique according the procedure described in the literature (Martí, et al. 2015). In order to remove secondary phases, the absorbers were chemically etching with diluted $\mathrm{KCN}$. Immediately, the solar cells were completed depositing CdS $(60 \mathrm{~nm})$ by chemical bath deposition (CBD) above the absorber layers. The $\mathrm{i}-\mathrm{ZnO}$ layer with $50 \mathrm{~nm}$ thickness was deposited by the DC-pulsed sputtering deposition using $\mathrm{ZnO}$ target and $\mathrm{Ar} / \mathrm{O}_{2}$ mixture as process gas. The cells were completed with the deposition of a conductive indium tin oxide (ITO). For the optoelectronic characterization $3 \times 3 \mathrm{~mm}^{2}$ cells were scribed using a micro diamond scriber MR200 OEG.

\subsection{Characterization techniques}

Enamel composition has been studied by X-Ray Fluorescence (XRF), using a sequential spectrometer X-ray scattering wavelengths S4 Pioneer by Bruker with a Rh X-ray tube of $4 \mathrm{~kW}$. The enamel surfaces were studied by Atomic Force Microscope (AFM) with a JSPM-5200 JEOL Scanning Probe Microscope operating in contact approach. The sheet resistance ( $R_{\text {sheet }}$ ) of the molybdenum back contact layers was measured with the 4-point probe method.

The crystal structure of enamels and the CIGS films were monitored by X-ray diffraction (XRD) using a D4 Endeavor, Bruker-AXS equipped with a $\mathrm{Cu}$ Ka radiation source. Data was collected by step-scanning from $10^{\circ}$ to $80^{\circ}$ with step size of $0.05^{\circ} 2 \theta$ and $1 \mathrm{~s}$ counting time per step. Scanning Electron Microscopy (SEM) model JEOL 7001F attached with an energy dispersive X-ray analysis (EDX) was employed to study the morphology and elemental composition of the films. The layer thickness was valued from cross-section micrographs. The solar cells were optoelectronically characterized through I-V curves. A Sun 3000 class AAA solar simulator from Abet Technology 
(uniform illumination area of $15 \times 15 \mathrm{~cm}^{2}$ ) was used. Measurements were carried out after the calibration of the system with a reference Si solar cell under AM 1.5 illumination and fixing the temperature of the samples to $298 \mathrm{~K}$. All solar cell parameters and efficiencies presented refer to the active area $\left(0.087 \mathrm{~cm}^{2}\right)$ of the devices. 


\section{Results}

Chemical analyses of alkali element detection in the enamels composition were determined by X-ray fluorescence (XRF). It has to be mentioned, that the enamels are commercials products and it exact chemical composition is a confidential issue. Thus, data referred only to $\mathrm{Na}_{2} \mathrm{O}$ and $\mathrm{K}_{2} \mathrm{O}$ content is exposed and discussed hereafter.

Table 1. Chemical analysis of the enamels performed by XRF.

\begin{tabular}{|c|c|c|c|c|c|}
\hline $\begin{array}{c}\text { Sample reference/ } \\
\text { alkali content (wt \%) }\end{array}$ & STD & A & B & C & D \\
\hline $\mathrm{Na}_{2} \mathrm{O}$ & 1 & 2 & 2 & 4 & 6.64 \\
\hline $\mathrm{K}_{2} \mathrm{O}$ & 1 & 4.2 & 4.6 & 3.20 & 2.20 \\
\hline $\mathrm{Na}_{2} \mathrm{O}+\mathrm{K}_{2} \mathrm{O}$ & 2 & 6.2 & 6.6 & 7.2 & 8.84 \\
\hline
\end{tabular}

The X-ray diffraction spectra of studied enamels are exposed in Figure 1. The STD sample is a glass-ceramic type glaze and shows some typical reflections corresponding to $\mathrm{ZrSiO}_{4}$ (JCPDS 006-0266) crystalline phase at (20): $20.19^{\circ}$ (101), $27.09^{\circ}$ (200), $35.73^{\circ}(112)$ and $53.55^{\circ}(312)$ and $\mathrm{SiO}_{2}$ cristobalite (101) (JCPDS 39-1425) glass former at $21.87^{\circ}$. The samples A, B and D show amorphous structure, while C displays also slight glass-ceramic nature deduced from the $\mathrm{ZrSiO}_{4}$ existence. 


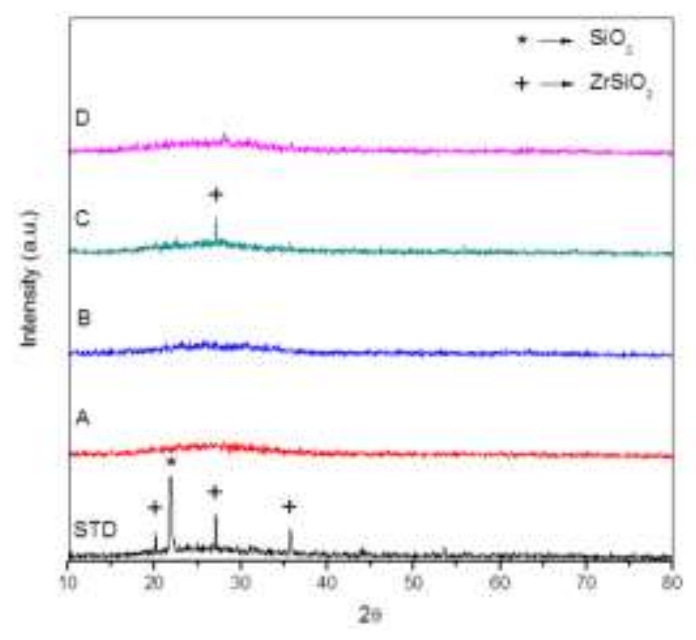

Figure 1. XRD data of the enamels.

Detailed surface morphological check is performed by AFM. The images are placed in Figure 2. Different surfaces can be observed in all samples. The lowest roughness is observed for samples STD and $\mathrm{A}(\mathrm{Ra}=8$ and $5 \mathrm{~nm}$ respectively), while the highest $(\mathrm{Ra}=41 \mathrm{~nm})$ for sample D. Visually; the smoothest sample is A as less dispersed crystals are found on the surface. The trend is that higher amount of alkali elements in the enamel increases surface roughness. The $\mathrm{Ra}$ of sample $\mathrm{C}$ is $\sim 19$ and the grains are homogeneously disperse on the surface, while sample D, with the highest Ra values, exhibit crystals heterogeneously distributed giving empty and mountains areas. It is challenging to perform adequate relation between the alkalis types present in the samples. 


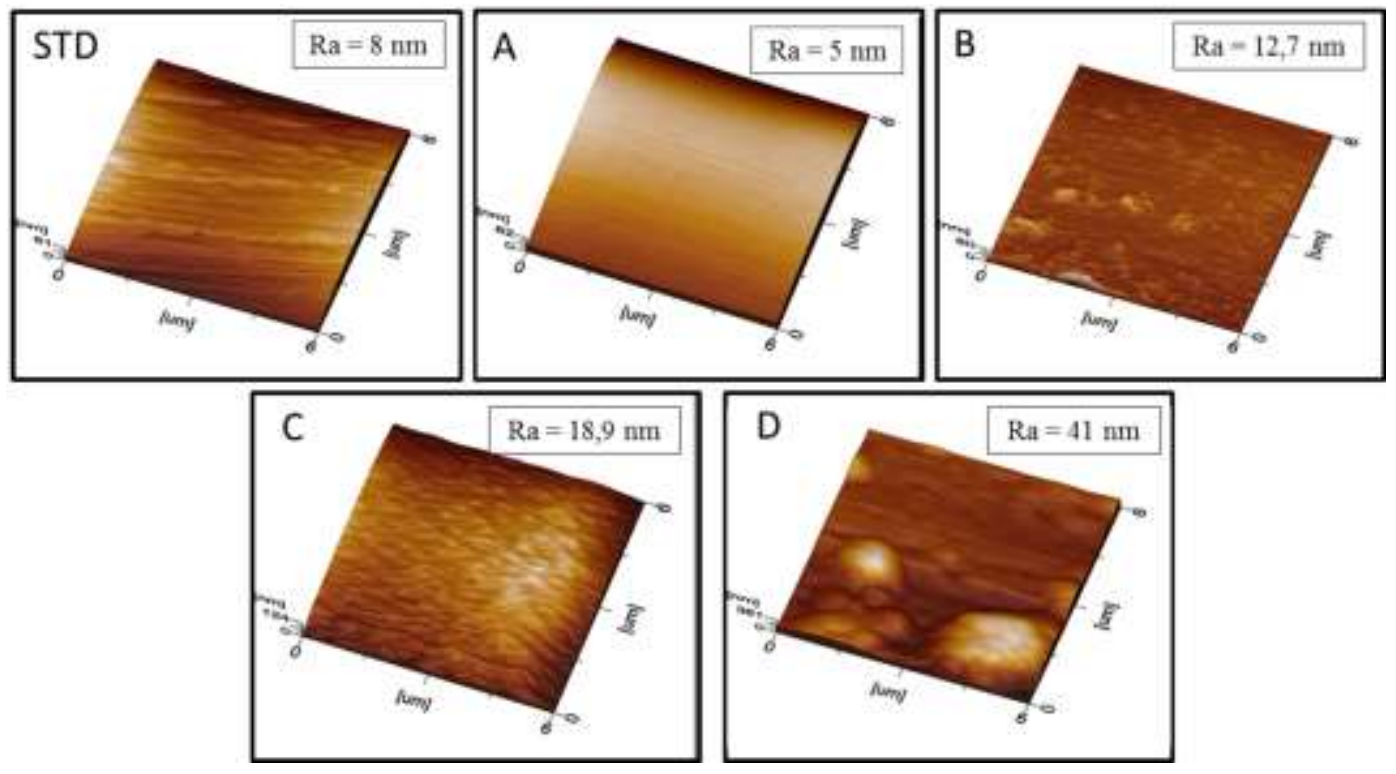

Figure 2. AFM images of enamelled ceramic substrates.

Figure 3 shows the surface morphology of the enamels, but observed under SEM conditions. The STD sample shows heterogeneous surface with many pinholes and some crystallization in agreement with the XRD results (Fig. 1). The samples A, B and $\mathrm{C}$ have similar and homogeneous appearance with almost any variations. Finally, the sample D (with the highest amount of alkali in the composition) clearly differs from the others with deteriorated surface. Thus, it can be concluded that the alkali elements affect to the layer morphology and the maximum quantity that do not failed the surface morphology corresponds to the chemical composition of sample $\mathrm{C}$ (4\% $\mathrm{Na} 2 \mathrm{O}$ and $3.20 \% \mathrm{~K} 2 \mathrm{O})$. 

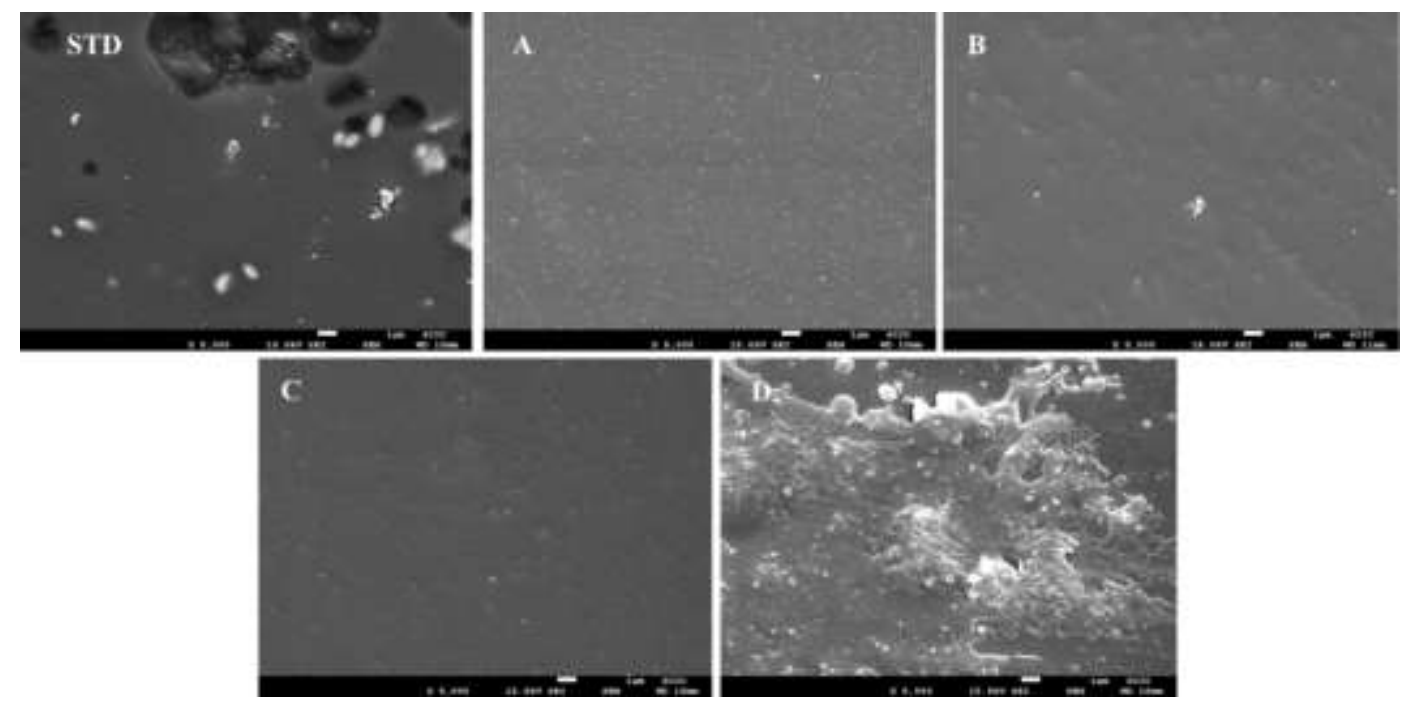

Figure 3. SEM surface images of the enamels.

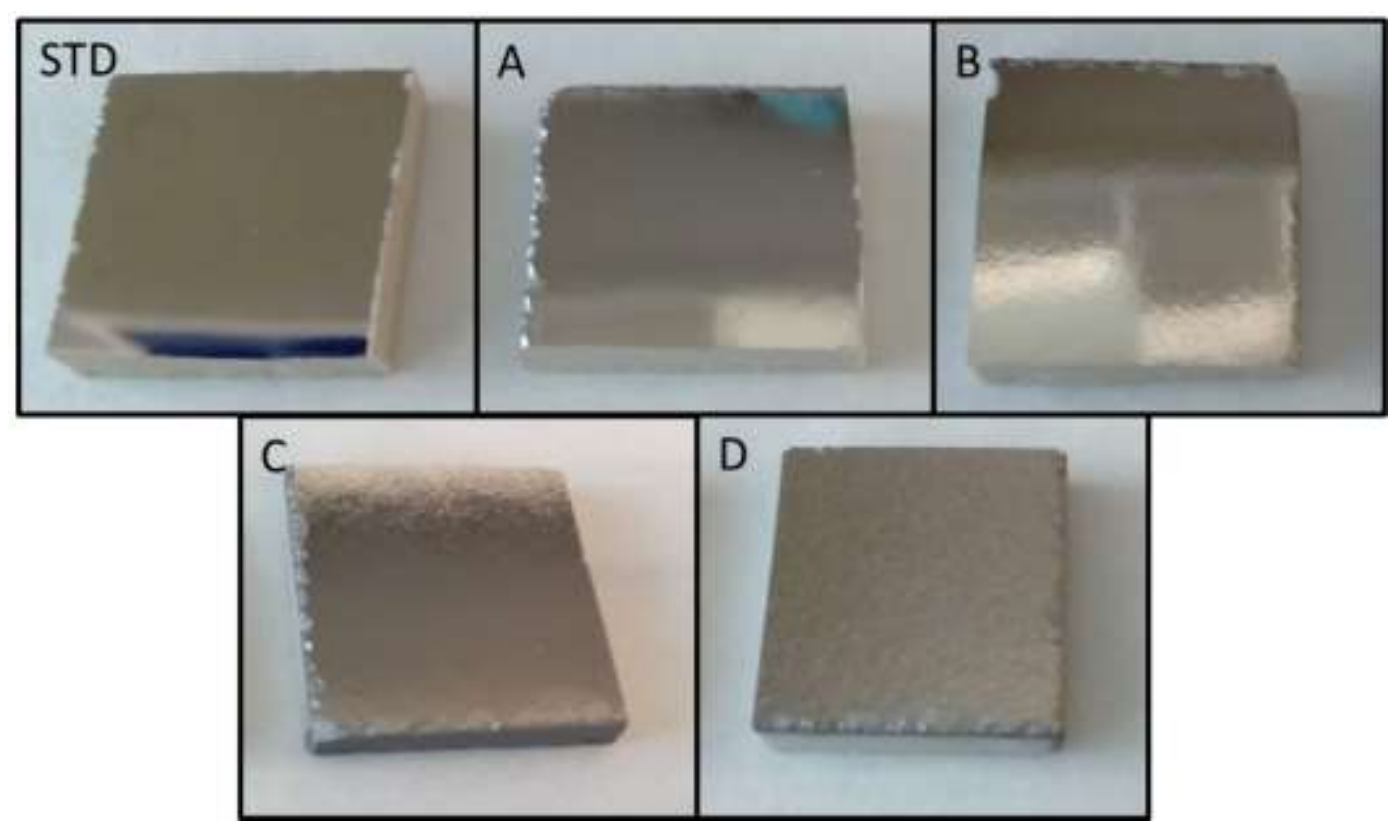

Figure 4. Enamelled ceramic substrate covered with molybdenum as back contact.

Molybdenum as back conductive contact was deposited on previously covered enamelled ceramic substrate using DC magnetron sputtering system (Alliance AC450). Figure 4 shown digital images of the different covered samples. These results are agreed with AFM and SEM images. Also, it can be observed visually the roughness increment with the alkali content. The different surface morphology of the ceramic substrates does 
not seem to harm the Mo back contact quality. The sheet conductivity was measured and exhibit $\mathrm{R}_{\text {sheet }}$ of $0.4 \Omega /$ sq for all samples.

The XRD patterns shown in Figure 5 correspond to the synthesized absorber and confirms that the resulting layer contain the $\mathrm{Cu}\left(\mathrm{In}_{0,7} \mathrm{Ga}_{0,3}\right) \mathrm{Se}_{2}$ compound (JCPDS 351102). The diffraction peaks labelled with $h k l$ correspond to the CIGS phase, while Mo (JCPDS 42-1120) back contact reflections are indicated by stars. Extra peaks were also detected at $2 \theta: 31.82^{\circ}$ and $53.07^{\circ}$ that could be assigned to $\mathrm{MoSe}_{2}$ phase (JCPDS 200757). Reflections at $2 \theta=21.8^{\circ}$, and $35.7^{\circ}$ corresponds to $\mathrm{SiO}_{2}$ cristobalite (JCDPS 391425) coming from the enamel.

Closer view of the CIGS main reflections (Fig.6), e.g. at $27^{\circ}$ for $h k l 112$, show shifting towards higher $2 \theta$ degree with increasing of the alkali quantity in the composition (for samples B, C and D). These results is associated with contraction of the unit cell that could be due to the higher amount of $\mathrm{Ga}$ incorporation in the crystal lattice as $\mathrm{rGa}^{3+}$ $(0.47 \AA)<\operatorname{rn}^{3+}(0.62 \AA)$ tetrahedrally coordinated (Shannon et al., 1976) (Shannon 1976). So, it can be related that alkali doping favor the Ga insertion in the lattice. The sample A seems to be an exception from this declaration as the peaks shifts towards lower 20. We couldn't explain this result.

These outcomes, could be related with the alkali diffusion mechanism discussed in the literature as Na distribution along the grain boundaries (Salomé, et al. 2015). Recently, have been reported that K could also diffuses toward CIGS (Salomé, et al. 2015) and it is possible that other elements from the enamel might have the same behavior. It has been debated that $\mathrm{K}$ reduce the overall amount of $\mathrm{Na}$ and thus allowed a higher $\mathrm{Cd}$ diffusion into $\mathrm{CdS}$ without changing in microstructure of the CIGS layer and this increase the cell efficiency (Chirilă, et al. 2011). This statement settles the degree of 
diffusion starting from the support, passing through the back contact and absorber coating and finally ending to the buffer layer $(\mathrm{CdS})$.

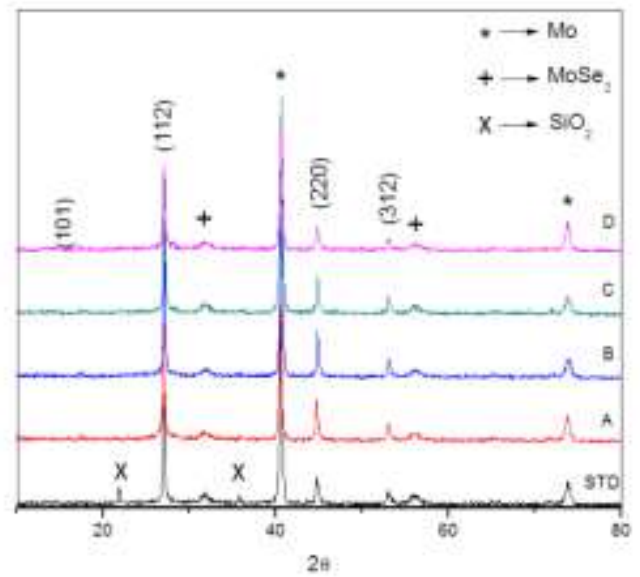

Figure 5. XRD data of the CIGS films prepared on ceramic tile with applied enamels.

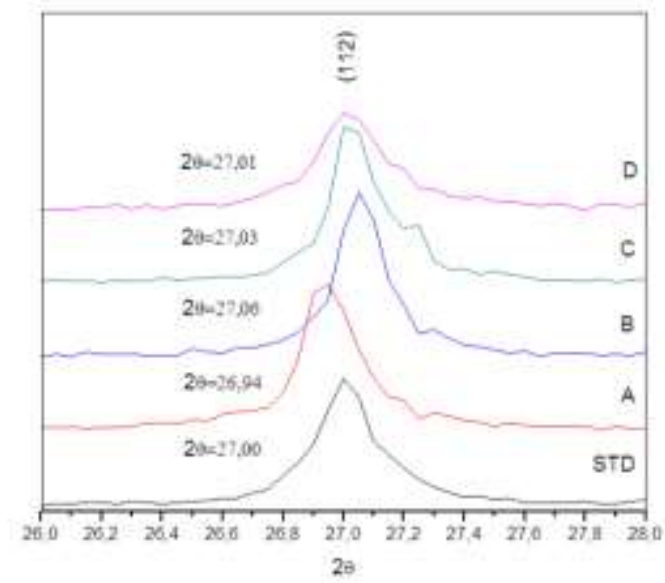

Figure 6. Zoomed section of XRD results. 


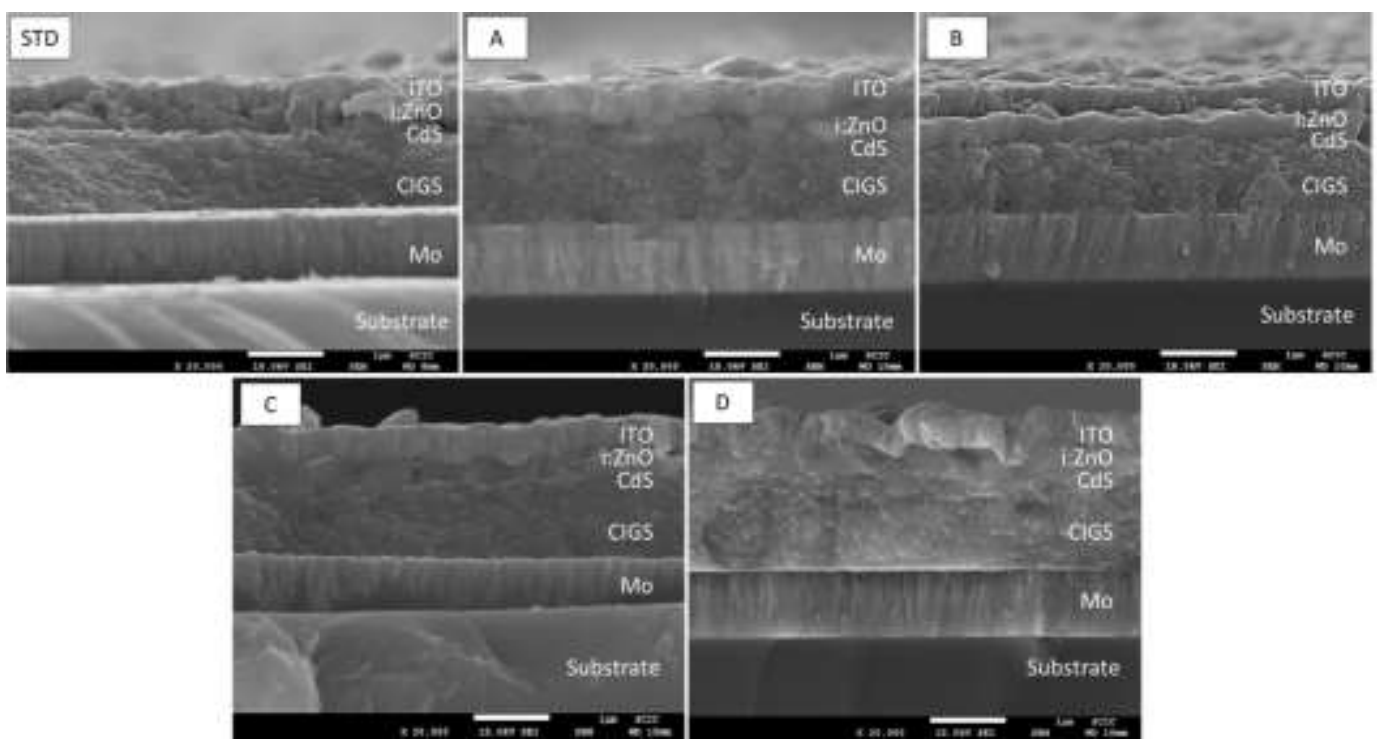

Figure 7. Cross section SEM images of CIGS device: STD, A, B, C and D

Figure 7 displays a cross section of the completed solar cells. The solar cells are composed by: enamel (bottom layer), followed by Mo coating ( $-800 \mathrm{~nm})$, absorber CIGS layer $(-1,5 \mu \mathrm{m}), \mathrm{CdS}$ buffer $(-20 \mathrm{~nm})$, zinc oxide $(-50 \mathrm{~nm})$ and ITO window layer $(-400$ $\mathrm{nm})$. In all cases, dense and well attached homogeneous layers are observed. The lack of larger grains could be related with the use of amine compounds during the synthesis procedure and with the thermal treatment applied. It is demonstrated that the amine binders inhibit the crystal growth (Lee and Yong 2013), an undesirable effect for the solar cell morphology and thermal cycle with slopes and retention times is also advisable. Here, the amines are used to enhance the reduction process and further CIGS formation, an essential step in the proposed synthesis procedure. As a conclusion, it can be resumed that after thermal treatment do not appear any morphological differences as a function of the alkali content.

In order to determine the dopant disuse mechanism, an EDX line profile was measured only for sample C (Fig. 8), selected as optimum. The results confirmed the presence of sodium and potassium in the enamel. The elemental detection corresponding of the rest of the layers was also correct. The diffusion of alkali elements from enamel towards the 
CIGS absorber layer was not clear by the performed EDX analysis. This fact could be due to overlapping of the spectral lines of $\mathrm{Na}$ and $\mathrm{Ga}$, and also $\mathrm{K}$ and In. So, the obtained result is ambiguous.

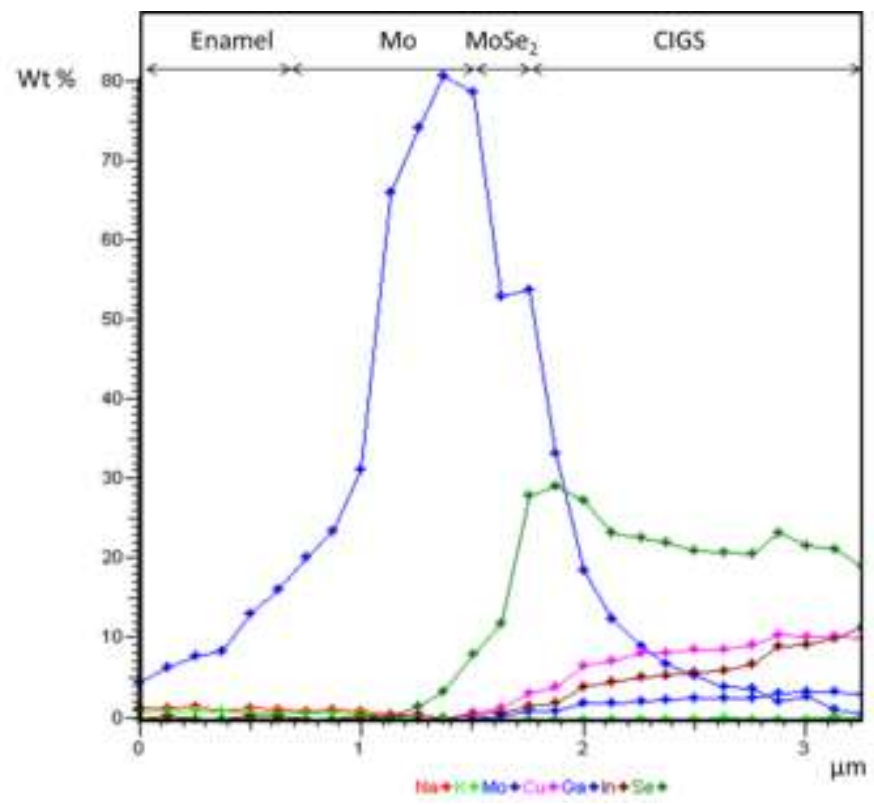

Figure 8. EDX line profile of the sample C.

The CIGS devices were optoelectronically characterized through current density-voltage (J-V) curves under AM1.5 global spectrum (Fig. 9). The photovoltaic behaviour is summarized in Table 2. 


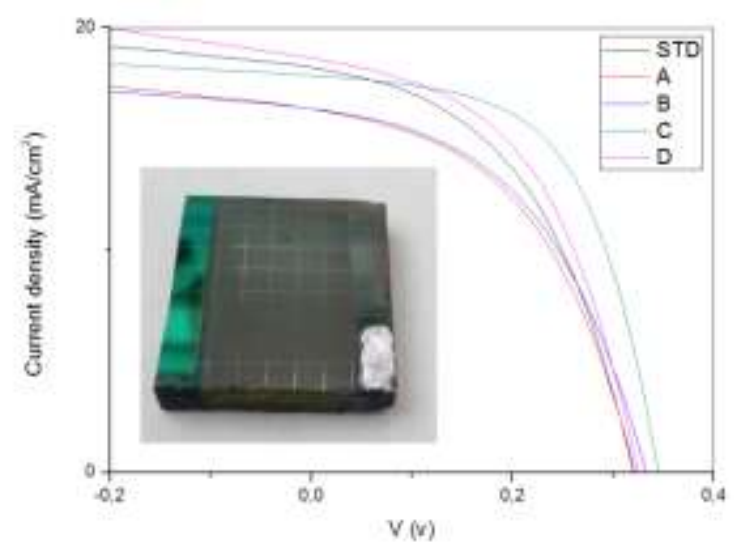

Figure 9. Current density $\left(\mathrm{mA} / \mathrm{cm}^{2}\right)$ vs voltage $(\mathrm{V})$.

Table 2. Summary of the optoelectronic parameters.

\begin{tabular}{|c|c|c|c|c|}
\hline & $\mathrm{Jsc}\left(\mathrm{mA} / \mathrm{cm}^{2}\right)$ & Voc $(\mathrm{mV})$ & FF $(\%)$ & Efficiency (\%) \\
\hline $\begin{array}{c}\text { Ceramic } \\
\text { without enamel }\end{array}$ & 5.49 & 89.5 & 28.5 & 0.1 \\
\hline STD & 18.0 & 319.3 & 47.4 & 2.7 \\
\hline A & 16.2 & 320.8 & 47.4 & 2.5 \\
\hline B & 16.2 & 332.1 & 47.3 & 2.6 \\
\hline C & 17.8 & 344.3 & 57.2 & 3.5 \\
\hline D & 18.5 & 323.9 & 49.5 & 3.0 \\
\hline
\end{tabular}

The photovoltaic parameters for the investigated solar cells summarized in Table 2. In the Table a "ceramic tile without enamel" data is displays for comparative reason. It can be seen that $0.1 \%$ conversion efficiency and inferior electrical parameters are obtained. It is evident that the enamel is compulsory cell component for the functionality of the photovoltaic tile. The best conversion efficiency is achieved for device C (Eff. $=3,5 \%$, which presents an improvement of $30 \%$ in efficiency compared to STD sample. Also, the device performance parameters such as opencircuit voltage (Voc) and fill factor (FF) are improved, while the short-circuit current density (Jsc) is the same in both cases. Sample D present an improvement of $10 \%$ in efficiency compared to STD sample and open circuit voltage and fill factor are slightly improved. The device B also showed a slight improvement in Eff, Voc and FF 
parameters. Sample A shows very similar to the STD behavior. Only a slight improvement in the $\mathrm{Voc}$ is observed. As a conclusion, the combination of $\mathrm{Na}$ and $\mathrm{K}$ incorporation in the enamel has positive influence on optoelectronic properties of CIGS devices. Other groups also observed a significant increasing in Voc and FF when $\mathrm{K}$ was used (Jackson, et al. 2014; Adrian Chirilă 2013).

Solar cell efficiencies and surface roughness were plotted vs $\%$ wt alkali concentration (Fig. 10). It can be observed the dependence of roughness with the alkali concentration. The trend is that efficiency increases with the concentration of alkaline until it reaches a maximum efficiency of $3.5 \%$ and a roughness of $18.9 \mathrm{~nm}$. From this point, the efficiency begins to decrease.

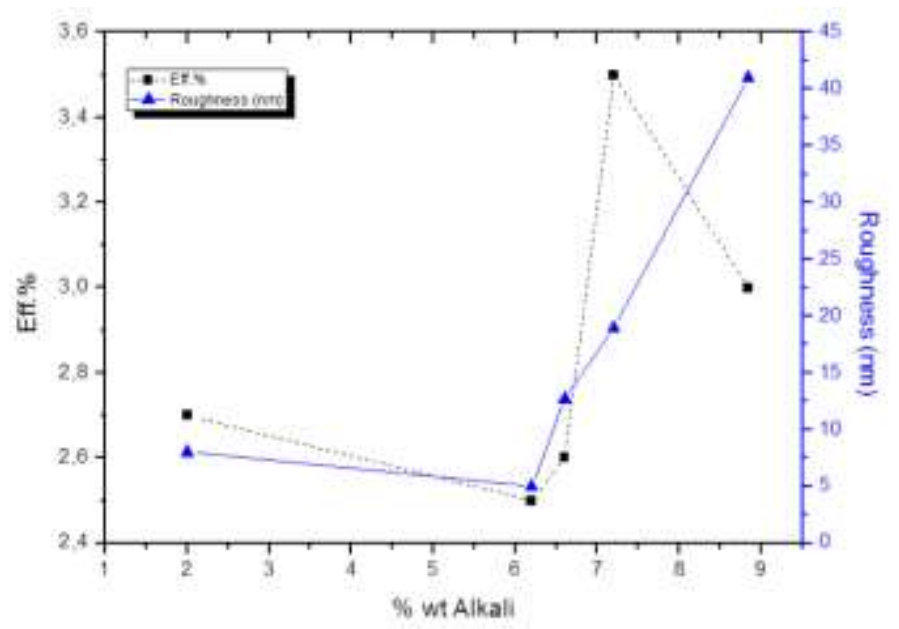

Figure 10. Solar cell efficiencies vs enamel roughness and alkali content. 


\section{Conclusion}

The effect of alkali doping in the CIGS photovoltaic ceramic tile have been investigated. Several ceramic enamels with altered chemical composition in terms of amount of alkali metals have been tested and compared. It is demonstrated that enamel barrier layer is compulsory cell component for the functionality of the solar cell device. It was quantify the optimum amount of alkali (i.e $4 \%$ wt $\mathrm{Na}_{2} \mathrm{O}$ and $3.2 \%$ wt. $\mathrm{K}_{2} \mathrm{O}$ ) that provides the best conversion efficiency of $3.5 \%$ for the CIGS solar cell. It was also observed that the alkali affect structurally by improving of $\mathrm{Ga}$ incorporation in the CIGS crystal lattice. The combination of both alkali ( $\mathrm{Na}$ and $\mathrm{K})$ increase an open-circuit voltage (Voc), fill factor (FF) and efficiency of the final device.

\section{Acknowledgements}

The authors would like to acknowledge the financial support of the Spanish Ministry of Economy and Competitiveness under the program RETOS-COLABORACION (RTC2014-2294-3). We also appreciate the characterization assistance of Central Service of

Scientific Instrumentation (SCIC) at the University Jaume I. We appreciate the Torrecid Group S.A. for the ceramic tiles supplying. The authors thank the group of A. Perez (Catalonia Institute for Energy Research-IREC) for the help in the solar cell assemble. 


\section{References}

El Chaar, L., lamont, L.A., El Zein, N., 2011. Review of photovoltaic technologies. Renew. Sust. Energ. Rev. 15, 2165-2175.

Park, S.-U., Sharma, R., Ashok, K., Kang, S., Sim, J.-K., Lee, C.-R., 2012. A study on composition, structure and optical properties of copper-poor CIGS thin film deposited by sequential sputtering of $\mathrm{CuGa/In}$ and $\mathrm{In} /(\mathrm{CuGa}+\mathrm{In})$ precursors. J. Cryst. Growth 359, 1-10.

Todorov, T.K., Cordoncillo, E., Sanchez-Royo, J.F., Carda, J., Escribano, P., 2006. CulnS2 Films for Photovoltaic Applications Deposited by a Low-Cost Method. Chem. Mater. 18, 31453150.

Todorov, T.K., Gunawan, O., Gokmen, T., Mitzi, D.B., 2013. Solution-processed $\mathrm{Cu}(\mathrm{In}, \mathrm{Ga})(\mathrm{S}, \mathrm{Se}) 2$ absorber yielding a $15.2 \%$ efficient solar cell. Prog. Photovoltaics $21,82-$ 87.

Jung, S., Ahn, S., Yun, J.H., Gwak, J., Kim, D., Yoon, K., 2010. Effects of Ga contents on properties of CIGS thin films and solar cells fabricated by co-evaporation technique. Curr. Appl. Phys. 10, 990-996.

Contreras, M.A., Romero, M.J., Noufi, R., 2006. Characterization of $\mathrm{Cu}(\mathrm{In}, \mathrm{Ga}) \mathrm{Se} 2$ materials used in record performance solar cells. Thin Solid Films 511-512, 51-54.

Reinhard, P., Buecheler, S., Tiwari, A.N., 2013. Technological status of $\mathrm{Cu}(\mathrm{In}, \mathrm{Ga})(\mathrm{Se}, \mathrm{S}) 2$-based photovoltaics. Sol. Energ. Mat. Sol. C. 119, 287-290.

Zhang, K., Yang, C.-I., Yin, L., Liu, Z., Song, Q.-m., Luo, H.-I., Xiong, Z.-y., Xu, M.-m., Xiao, X.-d., 2014. Fabricating highly efficient $\mathrm{Cu}(\mathrm{In}, \mathrm{Ga}) \mathrm{Se} 2$ solar cells at low glass-substrate temperature by active gallium grading control. Sol. Energ. Mat. Sol. C. 120, 253-258.

Furue, S., Ishizuka, S., Yamada, A., lioka, M., Higuchi, H., Shibata, H., Niki, S., 2013. $\mathrm{Cu}(\mathrm{In}, \mathrm{Ga}) \mathrm{Se} 2$ solar cells and mini-modules fabricated on thin soda-lime glass substrates. Sol. Energ. Mat. Sol. C. 119, 163-168.

Park, S.J., Lee, E., Jeon, H.S., Ahn, S.J., Oh, M.-K., Min, B.K., 2011. A comparative study of solution based CIGS thin film growth on different glass substrates. Appl. Surf. Sci. 258, 120-125.

Reinhard, P., Pianezzi, F., Kranz, L., Nishiwaki, S., Chirilă, A., Buecheler, S., Tiwari, A.N., 2015. Flexible $\mathrm{Cu}(\mathrm{In}, \mathrm{Ga}) \mathrm{Se} 2$ solar cells with reduced absorber thickness. Prog. Photovoltaics 23, 281-289.

Chirilă, A., Buecheler, S., Pianezzi, F., Bloesch, P., Gretener, C., Uhl, A.R., Fella, C., Kranz, L., Perrenoud, J., Seyrling, S., Verma, R., Nishiwaki, S., Romanyuk, Y.E., Bilger, G., Tiwari, A.N., 2011. Highly efficient $\mathrm{Cu}(\mathrm{In}, \mathrm{Ga}) \mathrm{Se} 2$ solar cells grown on flexible polymer films. Nat. Mater. $10,857-861$.

Caballero, R., Kaufmann, C.A., Eisenbarth, T., Unold, T., Klenk, R., Schock, H.-W., 2011. High efficiency low temperature grown $\mathrm{Cu}(\mathrm{In}, \mathrm{Ga}) \mathrm{Se} 2$ thin film solar cells on flexible substrates using NaF precursor layers. Prog. Photovoltaics 19, 547-551.

Pianezzi, F., Chirilă, A., Blösch, P., Seyrling, S., Buecheler, S., Kranz, L., Fella, C., Tiwari, A.N., 2012. Electronic properties of $\mathrm{Cu}(\mathrm{In}, \mathrm{Ga}) \mathrm{Se2}$ solar cells on stainless steel foils without diffusion barrier. Prog. Photovoltaics 20, 253-259.

Liang, X., Zhu, H., Chen, J., Zhou, D., Zhang, C., Guo, Y., Niu, X., Li, Z., Mai, Y., 2016. Substrate temperature optimization for $\mathrm{Cu}(\mathrm{In}, \mathrm{Ga}) \mathrm{Se} 2$ solar cells on flexible stainless steels. Appl. Surf. Sci. 368, 464-469.

Wuerz, R., Eicke, A., Kessler, F., Paetel, S., Efimenko, S., Schlegel, C., 2012. CIGS thin-film solar cells and modules on enamelled steel substrates. Sol. Energ. Mat. Sol. C. 100, 132-137.

Fraga, D., Stoyanova Lyubenova, T., Martí, R., Calvet, I., Barrachina, E., Carda, J.B., 2016. Ecologic ceramic substrates for CIGS solar cells. Ceram. Int. 42, 7148-7154.

Calvet, I., Barrachina, E., Martí, R., Fraga, D., Stoyanova Lyubenova, T., Carda, J.B., 2015. Development of photovoltaic ceramic tile based on CZTSSe absorber. Mater. Lett. 161, 636-639. 
Fraga, D., Lyubenova, T.S., Rey, A., Calvet, I., Martí, R., Carda, J.B., 2015. Ceramic Enamels as New Back Contacts for Cu (In, Ga) Se2-Based Photovoltaic Tile. Int. J. Appl. Ceram. Tec. 12, 728-737.

Calvet, I., Barrachina, E., Martí, R., Fraga, D., Lyubenova, T.S., Carda, J.B., 2015. Synthesis, deposition and crystal growth of CZTS nanoparticles onto ceramic tiles. Bol. Soc. Esp. Ceram. V. 54, 175-180.

Salomé, P.M.P., Rodriguez-Alvarez, H., Sadewasser, S., 2015. Incorporation of alkali metals in chalcogenide solar cells. Sol. Energ. Mat. Sol. C. 143, 9-20.

Theelen, M., Daume, F., 2016. Stability of $\mathrm{Cu}(\mathrm{In}, \mathrm{Ga}) \mathrm{Se} 2$ solar cells: A literature review. Sol. Energy 133, 586-627.

Rudmann, D., Brémaud, D., da Cunha, A.F., Bilger, G., Strohm, A., Kaelin, M., Zogg, H., Tiwari, A.N., 2005. Sodium incorporation strategies for $\mathrm{CIGS}$ growth at different temperatures. Thin Solid Films 480-481, 55-60.

Eid, J., Usman, A., Gereige, I., Duren, J.V., Lyssenko, V., Leo, K., Mohammed, O.F., 2015. Ultrafast pump-probe reflectance spectroscopy: Why sodium makes $\mathrm{Cu}(\mathrm{In}, \mathrm{Ga}) \mathrm{Se} 2$ solar cells better. Sol. Energ. Mat. Sol. C. 140, 33-37.

He, X., Liu, J., Ye, Q., Luo, K., Jiang, Y., Liao, C., Ouyang, L., Zhuang, D., Mei, J., Lau, W., 2016. The role of $\mathrm{Na}$ incorporation in the low-temperature processed CIGS thin film solar cells using post deposition treatment. J. Alloy. Compd. 658, 12-18.

Hsu, C.-H., Su, Y.-S., Wei, S.-Y., Chen, C.-H., Ho, W.-H., Chang, C., Wu, Y.-H., Lin, C.-J., Lai, C.-H., 2015. Na-induced efficiency boost for Se-deficient $\mathrm{Cu}(\mathrm{In}, \mathrm{Ga}) \mathrm{Se2}$ solar cells. Prog. Photovoltaics 23, 1621-1629.

Moriwaki, K., Nomoto, M., Ishizuka, S., Mukai, A., Sato, K., Kobayashi, H., Niki, S., 2015. Effects of alkali-metal block layer to enhance $\mathrm{Na}$ diffusion into $\mathrm{Cu}(\mathrm{in}, \mathrm{Ga}) \mathrm{Se} 2$ absorber on flexible solar cells. Sol. Energ. Mat. Sol. C. 133, 21-25.

Wuerz, R., Eicke, A., Kessler, F., Rogin, P., Yazdani-Assl, O., 2011. Alternative sodium sources for $\mathrm{Cu}(\mathrm{In}, \mathrm{Ga}) \mathrm{Se2}$ thin-film solar cells on flexible substrates. Thin Solid Films 519, 72687271.

Reinhard, P., Bissig, B., Pianezzi, F., Avancini, E., Hagendorfer, H., Keller, D., Fuchs, P., Döbeli, M., Vigo, C., Crivelli, P., Nishiwaki, S., Buecheler, S., Tiwari, A.N., 2015. Features of KF and $\mathrm{NaF}$ Postdeposition Treatments of $\mathrm{Cu}(\mathrm{In}, \mathrm{Ga}) \mathrm{Se} 2$ Absorbers for High Efficiency Thin Film Solar Cells. Chem. Mater. 27, 5755-5764.

Laemmle, A., Wuerz, R., Powalla, M., 2015. Investigation of the effect of potassium on $\mathrm{Cu}(\mathrm{In}, \mathrm{Ga}) \mathrm{Se} 2$ layers and solar cells. Thin Solid Films 582, 27-30.

Lee, M., Lee, S.M., Jung, S., Ahn, S., Cho, J.-S., Park, J., Eh, Y., Gwak, J., Shin, K., Yoon, K., Cho, Y.S., Yun, J.H., 2015. Highly efficient flexible Culn0.7Ga0.3Se2 solar cells with a thick $\mathrm{Na} / \mathrm{Mo}$ layer deposited directly on stainless steel. Appl. Surf. Sci. 346, 562-566.

Becerril-Romero, I., Giraldo, S., López-Marino, S., Placidi, M., Sánchez, Y., Sylla, D., PérezRodríguez, A., Saucedo, E., Pistor, P., 2016. Vitreous enamel as sodium source for efficient kesterite solar cells on commercial ceramic tiles. Sol. Energ. Mat. Sol. C. 154, 11-17.

Casasola, R., Rincón, J.M., Romero, M., 2011. Glass-ceramic glazes for ceramic tiles: a review. J. Mater. Sci. 47, 553-582.

Nandi, V.S., Raupp-Pereira, F., Montedo, O.R.K., Oliveira, A.P.N., 2015. The use of ceramic sludge and recycled glass to obtain engobes for manufacturing ceramic tiles. J. Clean. Prod. 86, 461-470.

Siligardi, C., Lusvarghi, L., Giolli, C., Scrivani, A., Venturelli, D., 2014. Recycling in ceramic glazes of zirconia overspray from thermal barrier coatings manufacturing. J. Eur. Ceram. Soc. 34, 147-154.

Martí, R., Oliveira, L., Lyubenova, T.S., Todorov, T., Chassaing, E., Lincot, D., Carda, J.B., 2015. Preparation of $\mathrm{Cu}(\mathrm{In}, \mathrm{Ga}) \mathrm{Se} 2$ photovoltaic absorbers by an aqueous metal selenite coprecipitation route. J. Alloy. Compd. 650, 907-911. 
Shannon, R.D., 1976. Revised Effective Ionic Radii and Systematic Studies of Interatomic Distances in Halides and Chalcogenides. Acta Crystallogr. A32, 751-767.

Lee, D., Yong, K., 2013. Non-vacuum deposition of CIGS absorber films for low-cost thin film solar cells. Korean J. Chem. Eng. 30, 1347-1358.

Jackson, P., Hariskos, D., Wuerz, R., Wischmann, W., Powalla, M., 2014. Compositional investigation of potassium doped $\mathrm{Cu}(\mathrm{In}, \mathrm{Ga}) \mathrm{Se2}$ solar cells with efficiencies up to $20.8 \%$. Phys. Status Solidi (RRL) 8, 219-222.

Adrian Chirilă, P.R., Fabian Pianezzi, Patrick Bloesch, Alexander R. Uhl, Carolin Fella, Lukas Kranz, Debora Keller, Christina Gretener, Harald Hagendorfer, Dominik Jaeger, Rolf Erni, Shiro Nishiwaki, Stephan Buecheler and Ayodhya N. Tiwari, 2013. Potassiuminduced surface modification of $\mathrm{Cu}(\mathrm{In}, \mathrm{Ga}) \mathrm{Se} 2$ thin films for high-efficiency solar cells. Nat. Mater. 12, 1107-1111. 